\title{
The Use of a Competency-based Approach to Forming Professional Culture in Pre-service Lawyers
}

\author{
Sergey V. Petkov ${ }^{1}$, Serhii F. Denysov ${ }^{2}$, Ganna S. Yermakova ${ }^{3}$, Viktoria M. Palchenkova ${ }^{4} \&$ Viktoriia M. Vovk $^{5}$ \\ ${ }^{1}$ Alfred Nobel University, Dnipro, Ukraine \\ ${ }^{2}$ Kharkiv National University of Internal Affairs, Kharkiv, Ukraine \\ ${ }^{3}$ Institute of Legislation of the Verkhovna Rada of Ukraine, Kyiv, Ukraine \\ ${ }^{4}$ National University “Zaporizhzhya Polytechnic”, Zaporizhzhia, Ukraine \\ ${ }^{5}$ Khmelnytsky University of Management and Law Named after Leonid Yuzkov, Khmelnitsky, Ukraine \\ Correspondence: Sergey V. Petkov, Alfred Nobel University, 18 Sicheslavskaya Naberezhnaya str., Dnipro, 49000, \\ Ukraine.
}

Received: June 10, 2020

Accepted: August 3, 2020

Online Published: August 14, 2020

doi:10.5430/ijhe.v9n7p367

URL: https://doi.org/10.5430/ijhe.v9n7p367

\begin{abstract}
The article foregrounds the problem of forming professional culture in the preparation of future lawyers based on the competency-based approach. It also focuses on problems related to its implementation in the educational process of a modern education institution. The research reveals the essence and structure of a future lawyer's professional culture. Thus, a lawyer's professional culture is a set of various cultural components (esthetic, legal, informational, economic, and political) and legal rules put forward to a lawyer while performing his/her main functions and professional principles. A questionnaire survey has been carried out to identify students' attitudes towards a supervisor and his/her impact on forming professional culture. In addition, to diagnose a level of professional culture formation, a psychological study has been conducted based on students' personal and professional qualities. The research has provided the assessment of socially educational work at the Law Faculty at Taras Shevchenko National University of Kyiv. It has been stated that the creation of certain psychological and pedagogical conditions for forming the professional culture of the student youth is one of the priorities of socially educational work at the Faculty. The main forms of socially educational work directed towards forming the professional culture of future lawyers are educational talks, seminars, a case-method, thematic meetings, student conferences, excursions, business and simulations, meetings with experienced practitioners, etc. Besides, the originally designed integrative course entitled "Professional culture of a specialist" has been implemented in the educational process. It uses the main principles of the competency-based approach to training students for their job as a lawyer as well as to demonstrate the main forms, methods, and techniques of working with different subjects. This process required the application of interactive teaching methods. It has been specified that the implementation of the competency-based approach to legal education enables us to determine its substantive content and impact. It provides an adequate standard for the professional culture of future lawyers.
\end{abstract}

Keywords: professional culture, interactive teaching methods, psychological and pedagogical education, integrative course, supervisors, competent approach

\section{Introduction}

Nowadays, the educational process realisation in a higher legal institution requires fundamental changes, bringing all its components into conformity with new conditions of professional work. In this regard, the focus of the education process on the future lawyers' competencies formation and development is an essential task. The above is consistent with the National Strategy of Education Development in Ukraine for 2021 stating that the main element of key directions of the educational sphere must be the modernisation of the educational structure and content through the competent approach. The key competencies suggested by The Council of Europe incorporated into the basis of the competent approach are divided into three categories: an independent action; interactive use of means; an ability to operate in socially heterogeneous groups (Antoniuk, Vasylkova, Ilnytskii, Kulaga \& Turchaninova, 2016). This particular approach ensures the high level of professional development of a future lawyer. The competency-based approach used in learning activities must be directed towards the achievement of effective results. Competence 
gained during learning activities is integrated into student's possibilities, which include productive knowledge, skills, practical experience, values, and attitudes that can be holistically realized in practice. Competency is regarded as a socially recognised level of knowledge, skills, abilities, and attitudes in a certain sphere of human activity (Krasnolutskii, 2013). However, unlike these conclusions, several studies either found advantages of traditional approaches of education or did not lead to the differences in educational modes at all. Trying to demonstrate that the educational environment has to be directed towards students, the research encourages the use of the competent approach in education (Baeten, Struyven \& Dochy, 2013).

Establishing Ukraine as a democratic state and its integration into the world community requires the improvement of professional training in forming a specialist's personality in all spheres of social life, especially in education. First of all, it is necessary to upgrade the educational system and the social education of lawyers, because the impact on the establishment and development of Ukraine as a social and legal country is realized due to their professional work. Since the main mission of a lawyer is the protection of rights, freedoms and legal interests of entities and individuals, provision of assistance, and proper litigation support of this category and other subjects (Rukolianska, 2015), a need for scientific study and reasoning of the content, principles and main ways to form the professional culture of future lawyers is presented in higher education institutions. The requirement of modern society is a high level of future lawyers' professional culture. It is explained by the fact that successful cooperation with the authorities in Ukraine depends on the professionalism of specialists in the legal sphere (Sylantiev \& Inshyn, 2018).

Taking into account the stated above, the topical problem is forming the professional culture of future lawyers in the process of their professional training. Thus, the search for ways to improve socially educational and educational work in a legal higher education institution is particularly important. Now there is a need for future lawyers to have ethical, moral, personal, and professional qualities with the help of which the impact on democratic transformations are happening in Ukrainian society.

\section{Literature Review}

The literature review found that a pre-service lawyer is considered a specialist who has a diploma of higher legal education and, what is more important, who is a medium of a certain intellectual elite of our society and has a calling to provide legal help to people in all spheres of vital functions. Due to his/her mission, a lawyer is a professional above all, the main credo of the work is to provide legal services by keeping to the principle of law prevailing, equality before the law and uphold the principles of justice while solving conflicts occurring in the social life of a person. In the first place, lawyers are defenders of ordinary people. Their main function is to protect the weak; contrary to that, a state, as a rule, is the strong suit. Thus, the protection of rights is often associated with the protection of human rights (Moley, 2014). The essence, content, and the nature of a lawyer's work are determined by its main aim, namely the protection of rights, freedoms and legal interests of a person, provision of effective, competent and highly qualified legal aid to the society and its institutes (Leahy et al., 2010). The importance of a liberal profession of a lawyer is supported and guaranteed by a permanent development of a society (European Commission, 2015), through the system of principles and sanctions on the national and European levels that set moral and professional criteria for legal practitioners. The researches demonstrate that a wide set of risks (legislative, judicial, commercial, information security, social and other) and threats exist in this sphere. In this aspect, the content of particular rules of the profession is a bright example of the fact that the profession of a lawyer plays a key role in supporting and improvement of national security (legal security, social security, economic security, etc.) taking into account lawyers' actions.

Analysing a modern lawyer's profile, it consists of a set of such elements as highly developed personal and professional qualities, productive knowledge, integrative abilities, and professional skills through which a future student will be able to explain legislative and other regulatory legal acts during the professional activity. Besides, $\mathrm{s} / \mathrm{he}$ will have an appropriate level of general and professional culture.

Value-orientation and professional mastership of a future lawyer depend directly on the awareness of a set of legal values and ethical rules in the society, a high level of the behaviour culture, human and professional dignity, reserved tact, tolerance, self-control, and stamina in the behaviour.

Nowadays, preparation of a modern lawyer specified by the prestige of a legal profession and respect to its representatives should be built on the following principles: "rule of the law" and legitimacy; honesty and good faith; competency; social accountability for the quality and timeliness of legal service provision to him/herself, society and the state. These particular principles determine the level of the professional culture of a future lawyer, the essence of which is to provide each student with the general cultural and professional system of values created by different generations of ethnic, national and regional human communities as well as by the holders of the legal profession 
themselves (Ministry of Education and Science of Ukraine, 2018).

Taking into account legal deontology (a science on particular professional behavior), the internal structure of the lawyer's professional culture consists of such fundamental elements of culture as ethical, esthetical, religious, political, economic, communicative, physical, and legal ones. The structure of a lawyer's professional culture suggested in the research will help a future specialist create especially sensitive legal consciousness, form professionally directed vision, and worldviews on reality. Lawyers' professional culture is a set of various types of culture. To understand fully suggested structure it is necessary to study each element independently.

Primarily, the important element of a lawyer's behavior is ethical culture. In professional work, a modern lawyer has to be guided by ethical rules of human behavior while communicating with clients, colleagues, and partners, officials, and political leaders and others. The main features of the ethical behavior of a future specialist in the legal sphere are politeness, tolerance, emotional restraint, the responsibility to him/herself and other people (Katsavets, 2017).

Understanding moral and esthetical values by a future specialist in the legal sphere as well as keeping to esthetical rules in the behavior characterizes the high level of professional legal work.

Besides, it should be mentioned that a legal profession is related to the political life of the society that is why the level of lawyer's political culture influences the level of the professional work. Knowledge about the real policy of the state and civil society indicates that a future lawyer will be able to analyze, assess and forecast the development of political processes, assess the legal situation, and influence the realisation of legal regulation (Voloshyna, 2016).

Another important element of a lawyer's general professional culture is economic culture. To get aware of the functioning of the economy of different European countries and their foreign economic relations with other countries is essential in the professional preparation of a lawyer because legal regulation of economic relations in the world countries is of great importance. For example, to protect human rights, a lawyer's internal reasons are important for him/her (Boukalas, 2013) because economic goals cannot explain delivering legal services free of charge.

It should be emphasised that the profession of a lawyer takes place through communication that is through both verbal (written and oral) and non-verbal (gestures and mimics) language. The level of language mastering itself characterizes the level of education and professionalism of a lawyer. While studying in higher education institutions a future specialist needs to have the appropriate vocabulary, and ability to build a speech correctly, to use and explain legal terms, to defend the legal position in front of interlocutors and clients not depending on the level of their general and legal education and culture. All these characteristics point to the high level of the lawyer's professional culture. In this context, taking into account the development of the world's globalization processes, mastering one of the languages spoken in the world community is important for a lawyer (Pechko, 2008).

Besides, during the performance of the professional work, it is necessary to use non-verbal means of communication, namely gestures and mimics, which help influence emotionally certain information perception by another person; make desirable psychological contact with a person, acquire, understand and recognize the information better (Semenog \& Nasilienko, 2015).

As is known, one requirement for the lawyer's effective work is the legal informatisation of the society, the goal of which is to inform the society and satisfy the informational needs of citizens. The information is the main means of professional work. Thus, the educational process must focus on the formation of informational culture as a system of knowledge, skills, and abilities of a lawyer in the sphere of informational and legal communication to perform successfully.

The next element of the lawyer's professional culture is psychological, which can be characterised as a system of psychological qualities formed while the cooperation of a specialist in the legal sphere and demands of legal processes. It is essential to draw attention to forming such psychological features as memory, emotions, senses, mood, stress resilience, global thinking, and creativity while professional training.

Legal culture is the last element in the list of structural components of a lawyer's professional culture. In our view, a lawyer's legal culture consists of professional legal knowledge, integrative abilities, and skills, knowledge from spheres of human's vital functions related to an appropriate area of legal regulation, legal consciousness, and lawful behavior of this profession medium.

Based on the stated above, the lawyer's professional culture is a set of various cultural and legal rules elements put forward to a lawyer while his/her performing of main functions and professional principles.

The educational process of higher education institutions that are preparing specialists in the sphere of law must 
provide development of high culture, humanistic worldview, and high moral standings among students as well as it has to revive patriotic feelings and high civil engagement of the students (Bondarenko, Bodenchuk, Krynytska \& Gayvoronska, 2019).

The solving of the problem stated above demands searching for innovative methods of educational and socially educational processes organization. It also needs learning form Ukrainian and foreign experience while lawyers' preparation.

Therefore, the attention should be focused on strengthening professional psychological and pedagogical training of future lawyers-professionals, preparing for successful professional work, and providing involvement of all students in professional culture.

To form the professional culture of future lawyers, the most wide-spread forms of socially educational work include socially educational talks, seminars, case-method, thematic meetings, student conferences, excursions, business and role games, meeting with famous practitioners, etc. The Law Faculty of Taras Shevchenko National University of Kyiv draws special attention to forming professional culture and socially educational work with students. The aim of future lawyers' education is comprehensive professional preparation of specialists in the legal sphere, development of legal, psychological, ethical, esthetic, economic, and informational culture among students. At Law Faculty, the main task of socially educational work is to secure the unity of educational and socially educational work among law students, creating conditions for the full development of their skills, permanent self-improvement, and forming a high level of professional culture. The increase of the supervisor's role as a medium of knowledge and culture who carries out the socially educational work management in student academic groups is especially important. A supervisor of students is a teacher who is credible and is distinguished by high moral qualities, who also has pedagogical skills, organizational and communicative qualities. To conduct effective socially educational work, supervisors hold seminars, round tables, discussions, presentations, and individual consultations (Tszia, 2016).

To help supervisors fulfill socially educational work among future specialists in the legal sphere in the process of forming professional culture, a round table "The basis of forming the professional culture of future lawyers" was held at the Law Faculty of Taras Shevchenko National University of Kyiv. During this event, participants discussed the main problems of forming professional culture, psychological aspects of communicative cooperation in academic groups. As (Stremmel, 2005) noticed, the supervisor's culture played an important role in their professional work.

The esthetical experience cannot be forced towards a personality. However, conditions can be created to provide some possibilities. It is a special experience intertwined with happiness, joy, increased vitality, and attention. It happens now and can lead to a "wow" experience (Uhrmacher, Moroye \& Conrad, 2016). A happy teacher who appreciates esthetic experience will create a positive atmosphere by using creative teaching methods regarded as a means of professional development (Chen, 2014; Lim, 2005).

Thus, based on the scientific analysis conducted in the research, a lawyer's professional culture can be regarded as an integrated practical and applicable legal science, which includes a set of productive knowledge about various cultures as well as scientific acquisitions of legal deontology and professional ethics. In contrast, it can be described as a professional feature of a specialist in the legal sphere that includes different norms, principles, and rules of ethical behavior, etc.

Thus, one of the main problems requiring detailed analysis, theoretical justification, and development of scientific and methodological provision is professional culture forming while preparing future lawyers.

The aim of the article is to identify and characterise theoretical means of forming professional culture in training future lawyers through the competent approach.

\section{Materials and Methods}

This study employed a quasi-experimental design. The variable for the study were students' communicative abilities, organisational abilities, reflection, creativity and empathy. The students' communicative and organisational abilities were measured using a quiz (The Lawyer Portal, n.d.). The reflection skills were measured using the scale designed by Ledvinka (2014). The role reversal method was used to measure creativity and empathy of the samples students (Yaniv, 2012).

Based on the methodological base of the research, the competency-based approach, the aim of which is to form a number of competencies (productive knowledge, integrative abilities, professional skills, attitudes, etc.) to be learned by the students while their studying in a higher education institution, has been used for forming the professional culture of students in the legal sphere. This approach transfers obtained knowledge to the area of formation and 
development of students' ability to act practically and use creatively their knowledge and experience in various situations. It allows developing a program of a psychological and pedagogical experiment, which was aimed at identifying the status of the problem and was conducted during the following stages:

The first stage was referred to as the theoretical analysis of literature on the topic under study. At this stage, psychological and pedagogical literature on the problem of the study was processed.

The second stage included the use of a questionnaire survey to identify the students' attitudes to their supervisor and his/her influence on forming professional culture. It enabled the detection of the biggest problems, which hampered the effective educational activity in the process of professional training, as well as means that helped best form the professional culture of future lawyers.

The third stage included a pedagogical experiment and psychological study of law students to identify the formed level of professional culture based on their personal and professional qualities.

Based on the analysis of psychological, pedagogical, and legal literature, it is noted that the structure of a lawyer's professional culture is characterised by such features as moral, pedagogical, psychological, political, and informational culture and so on. The pedagogical culture of a lawyer is studied by (Slyvka, 2000), "as a necessary and important part of the professional culture in general." Besides, as the author stated, the structure of pedagogical culture included such elements as personal (pedagogical focus, erudition, education, high value, and moral qualities) and activity-oriented (pedagogical mastery, creativity, the culture of pedagogical communication, and self-development).

Therefore, the actualisation of different scientists' views allows characterizing professional culture as an important element of the social and historical development of a society that includes the internal and external culture of a lawyer and influence on the formation of his/her personal and professional qualities. To date, a lawyer has to understand a comprehensive component and the importance of the profession. In doing so, s/he must have ethical, value, moral and legal rules of the society as well as formed spiritual principles. S/he should also keep to justice, validity, and good faith and be ready to help another person (Bakhov, 2014). In this context, good faith is regarded not only as a traditional element but as the professional duty of a lawyer (Buisseret, 2019). Psychology, business management, and management also point to personal immunity as an important criterion that enables to assess skills to fulfill work.

In the current context, the domestic psychological and pedagogical component of the study is essential. The educational process built on competent analysis influences the formation of professional culture and the value-moral qualities of students.

\subsection{Sample}

The pedagogical experiment was held at the Law Faculty of Taras Shevchenko National University of Kyiv (the number of respondents is 178 people). The analysis of the experiment among the 1 st $-3 \mathrm{~d}$-year students, the specialty "Law" demonstrated:

1. Academic performance (based on the results of tests and a module control): the first-year students - $16 \%$ excellent, $27 \%$ - good, $36 \%$ - satisfactory; $21 \%$ - unsatisfactory; the second-year students - $10 \%$ - excellent, $35 \%$ good, $32 \%$ - satisfactory, $33 \%$ - unsatisfactory; the third-year students - $23 \%$ - excellent, $25 \%$ - good, $41 \%$ satisfactory, $11 \%$ - unsatisfactory.

For example, foreign scientists suggest to use three criteria in their pedagogical studies: - the final interest of students, subjective achievement in studying and the development of academic competencies - and intermediary cognitive engagement - at the end of the term while final survey. They developed a six-position scale of cognitive participation, which embraced the cognitive aspects of behavioral cooperation (Jang, Kim, \& Reeve, 2016).

2. Communicative skills based on the methodology of communicative and organisational skills studying: the first-year - $8 \%$ - the high level, $36 \%$ - the average level, $56 \%$ - the low level; the second-year: $10 \%$ - the high level, $43 \%$ - the average level; $47 \%$ - the law level; the third-year - $21 \%$ - the high level, $42 \%$ - the average level, $37 \%$ the low level.

\subsection{Instruments}

A questionnaire-based survey and diagnostic methodologies of the variables were used as the instruments for this study. The questionnaire included four closed-ended questions. Coding procedure, content and discourse analysis were performed by the research team members to ensure the validity and reliability of the questionnaire. 
1. Is there any cooperation between law students and supervisors?

2. Are you satisfied with the supervisor's attitude?

3. Do you ask your supervisor for help or solving some problems?

4. Does a supervisor help you form personal and professional qualities?

The diagnostic methodologies were used to measure changes in students' communicative abilities, their organisational abilities, reflection, creativity and Empathy.

\section{Results}

The questionnaire survey on the topic "A supervisor through the eyes of students" was conducted among 1st -4th -year students at Law Faculty. The total number of respondents was 178 people. The results of the research are presented in Table 1.

Table 1. Results of the research on the topic "A supervisor through the eyes of students"

\begin{tabular}{lllll}
\hline$\#$ & Question & \multicolumn{3}{c}{ Answers } \\
\cline { 3 - 5 } & & Yes & No & Partially \\
\hline 1. & Is there any cooperation between law students and supervisors? & $60 \%$ & $10 \%$ & $30 \%$ \\
2. & Are you satisfied with the supervisor's attitude? & $75 \%$ & $15 \%$ & $10 \%$ \\
3. & Do you ask your supervisor for help or solving some problems? & $7 \%$ & $65 \%$ & $28 \%$ \\
4. & Does a supervisor help you form personal and professional qualities? & $54 \%$ & $20 \%$ & $26 \%$ \\
\hline
\end{tabular}

It should be noted that the questionnaire survey was held secretly. Analysing the results of the research, the following conclusion can be done: the supervisor's work is effective based on the response to the first question. The next question "Are you satisfied with the supervisor's attitude?" proves the positive dynamics in supervisors' work. Seventy-five percent of students answered "Yes," which demonstrates that supervisors do their socially educational work effectively and spend their free time for it using innovative methods and forms of an impact on a personality. Besides, they use multiple pushes and pull activities to form the professional culture of future lawyers. For example, they involve a crime laboratory, a mediation center; organize meetings with famous practitioners in the legal sphere; hold various legal contests and thematic hours of professional culture. However, there are some disadvantages. When answering the question "Do you ask your supervisor for help or solving some problems?" only 7\% of the students answered "Yes," and only 28\% - "Partially." It characterizes that a supervisor failed to establish personal communication with law students.

Based on the results of the research, some recommendations can be suggested. It is necessary to improve the process of socially educational work with law students. Firstly, supervisors have to improve forms of work, namely: to organise excursions to museums and theatres as well as they must organise professional excursions, for example, to the Supreme Council of Ukraine, Constitutional and Supreme Court of Ukraine and so on. The suggested forms of work will help supervisors increase the level of students' professional culture, unite students, build cooperation between students and supervisors, and increase the level of trust.

Therefore, only the focused and integrated work of supervisors can create a highly professional specialist in the legal sphere. Educational and socially educational works have to be directed towards a student's personality and ensure his/her involvement in the socially educational process based on cooperation, dialogue, and partnership.

Comparing subjects taught during the 1st-3d year at Law Faculty of Taras Shevchenko National University of Kyiv, we analyzed educational plans and programs in terms of possibilities to form the professional culture of law students by means of the subject. The analysis demonstrated that for the first-year students, the most effective means were training "Effective communication and interpersonal cooperation" and "interpersonal sensitivity" because these particular tools contributed to the first-year students' intensive self-development. At the same time, the increasing interest in the understanding of society and a personality was detected. In addition, the system of subjective attitudes, adaptation to a new team, and a new teaching system was also created.

To form professional culture, a "training of professional skills", a case-method, business, and role games were used during the second year of learning. The results of the pedagogical testing demonstrated that $52 \%$ of the students had "excellent," 25\% - "good," 20\% - "satisfactory," 3\% - "unsatisfactory." It was highlighted that the use of these 
activities and their successful mastering promoted the development of professional skills and legal culture.

The application of the appropriate interactive methodologies showed the formation level of students' attitude to the society, the intensive formation of vital and spiritual values of a personality. The assessment of their abilities became more adequate, the youth began to think about their future after graduation more seriously. However, since lessons are mainly understood as a wide decision, they include the participation of all people and need the use the support system, for example, working hours of a professor or additional resources (Fredricks, Filsecker \& Lawson, 2016). These studies hardly offer conclusions on the learning process. Moreover, visible participation is happening in small courses because they provide students with more opportunities to be engaged in professional behavior (for example, by doing an exercise). The same aspect of engagement can be found during lectures. Thus, it can be less mess in the course format: cognitive participation of students. It is also used in different disciplines while other cooperation activities can depend strongly on certain "culture" or "logistics" of a particular subject. To promote the discussion on effective teaching methods based on constructivism, the empirical proofs that can track the students' success in changeable results in their cognitive participation in a class are necessary. In turn, it was caused by appropriate teaching methods.

At the same time, the sense of the development and implementation of innovative teaching in the educational process of a higher education institution is not in the regency effect. It is in the increase of professional training quality of a comprehensively competent professional. It promotes the increase of cognitive activity of students, their interest in studying, development of initiatives and creative potential of everyone, and the emergence of possibilities for creative self-realisation and self-realisation itself.

To form productive knowledge, the method of project-based learning was used. It developed the law student's ability to think globally, to find and solve problems using knowledge from different spheres, to form integrative skills, to predict results and possible consequences of various options for solving; and the ability to find casual links.

To check the efficiency of active forms and methods of a work application, the author suggested test tasks aiming at expanding inter-intellectual possibilities of students; the interest to the material under study. The elements of emotionality and a lack of monotony in lectures created the stimulus to operative perception and understanding of the information. According to the results of the test, such rates were detected: 56\% - "excellent," 37\% - "good," and 7\% - "satisfactory."

During practice sessions teachers widely used such technologies of active teaching as plot-based role games, where the accent was made on the organization of professional, orientation, and individual work. Besides, they also used such a type of practical work as responding to problematic situations in the work with a client, where each participant suggested his/her option by grounding the position. To form the professional culture of future lawyers, the author's integrative course "Professional culture of a specialist", the aim of which is to guide students in main principles of the competent approach to the professional work of a lawyer, and to describe main forms, methods, and technologies of work with different subjects, was introduced. The stated above demanded the usage of interactive teaching methods (case situations, role and business games, projects, and training). In higher education institutions, integration of creativity into the course helps raise responsibility for the decision and actions towards yourself and other people (Kolstad, 2017).

In the process of psychological research with the help of methodologies, the main emphasis was made on learning communicative and organizational skills important for specialists in the legal sphere. It is explained by the fact that communicative ability itself synthesizes different elements of world view, moral, professional, physical, emotional and will qualities of a future lawyer personality as well as special knowledge, abilities, and skills, which impact greatly on means of transfer, application and storage of information (Romanenko \& Chaplay, 2016). Comprehension, the analysis of their professional work, actions, and behavior; identification of the main areas in the improvement of their professional work, all these are happening through professional reflection. "The methodology of studying the level of reflection" was aimed at the issues mentioned above. However, the focus should be done on self-reflection, which is a part of training and can be realized through effective intellectual activity, so that participants can share their educational experience. In the end, they will understand the value of self-reflection and it will lead to a new comprehension of their behavior and beliefs (Jones, Jenkin \& Lord, 2006). The integral part of the social worker's personality is not the only reflection; it is also creativity reflected in the student's ability to think and behave out of the box, to understand and develop professional and life experience. Determination of the creativity level is shown in the Wartegg's methodology "The circle."

The effective implementation of any professional activity in general and the social one, in particular, demands both reflection, creativity, and empathy as "understanding of the emotional state, and breaking into the experience of 
another person" through "Diagnostic methodologies of the level of empathic abilities". The data on the results of each methodology are given in Table 2.

Table 2. Results of the study of future lawyers' personal and professional qualities

\begin{tabular}{llll}
\hline Figures on methodologies & \multicolumn{2}{l}{ The students of Law Faculty (178 people) } \\
\hline Scales & The low level & The average level & The high level \\
Communicative abilities & $19 \%$ & $35 \%$ & $46 \%$ \\
Organisational abilities & $21 \%$ & $30 \%$ & $49 \%$ \\
Reflection & $9 \%$ & $26 \%$ & $65 \%$ \\
Creativity & $20 \%$ & $31 \%$ & $49 \%$ \\
Empathy & $10 \%$ & $25 \%$ & $65 \%$
\end{tabular}

Analysing the data obtained, the research observes that the professional preparation of specialists at the Law Faculty of Taras Shevchenko National University of Kyiv is productive.

\section{Discussion}

Modelling life situations, implementation of role games, common solving of problems based on the circumstances, and a certain situation analysis are used to realize creatively oriented educational processes with the application of interactive technologies. It "helps form skills and abilities, develop values, create an atmosphere of cooperation and collaboration that allows a teacher to become a real leader in a team."

Such exercises as "To know yourself" - helps students develop self-criticism and deepen their knowledge on themselves"; "The content of professional culture" - deepens knowledge on culture and help understand the importance of the component; "Responding to problematic situations" - help determine approaches and participants' level of communicative readiness to respond to problematic situations; "Theatre" - develops the ability to understand another person's position and feelings, abilities to establish contact with possible clients, colleagues and others; were actively and productively used in the teaching process.

We believe that the main tasks of socially educational work for students of law specialties are forming the professional culture of a lawyer, positive legal image, moral and ethical qualities of a lawyer's personality and his/her legal consciousness. As scientists state, the competent approach is the education process during which students will be able to deeply understand themselves, other people, and things around them. They will become more sympathetic and altruistic with such understanding (Nilchaikovit, 2008). They will improve their attitude from egocentrism to transparency, sympathy, and openness to alternatives. The process includes careful listening, esthetical conversation, reflective teaching, and relaxation (Waters, Barsky, Ridd \& Allen, 2015).

\section{Conclusion}

Thus, implementation of the competent approach into legal education enables to identify its substantive content and performance that secure the appropriate level of future lawyers' professional culture. The formation of professional culture among future specialists in the legal sphere is conditional upon growing social needs in a personality with a high level of personal and professional qualities. This particular system helps increase the level of future lawyers' professional culture. The competent approach guides educational goals at acquiring results influencing professional knowledge levels. It also directs at combining professional education and the needs of the society and the labor market; it demands the application of teaching methodologies that provide students not only with productive knowledge, integrative abilities, and professional skills but also with the experience in the professional work. Moreover, they inculcate self-confidence, readiness to take responsibility for their actions and decisions, which is especially important for a future lawyer, etc.

\section{Acknowlegements}

We are grateful to all participants of the university for this research and the possibility to finish it smoothly. 


\section{References}

Antoniuk, L. L. Vasylkova, N. V., Ilnytskii, D. O., Kulaga, I. V., \& Turchaninova, V. E. (2016). The competent approach in higher education: the world experience. Kyiv, Ukraine: National Economic University named after Vadym Hetman.

Baeten, M., Struyven, K., \& Dochy, F. (2013). Student-centered teaching methods: Can they optimise students' approaches to learning in professional higher education? Studies In Educational Evaluation, 39(1), 14-22. https://doi.org/10.1016/j.stueduc.2012.11.001

Bakhov, I. S. (2014). Dialogue of cultures in multicultural education. World Applied Sciences Journal, 29(1), 106-109. https://doi.org/10.5829/idosi.wasj.2014.29.01.13775

Bondarenko, S., Bodenchuk, L., Krynytska, O., \& Gayvoronska I. (2019). Modelling instruments in risk management. International Journal of Civil Engineering and Technology, 10(01), 1561-1568.

Boukalas, C. (2013). Politics as legal action/lawyers as political actors: Towards a reconceptualisation of cause lawyering. Social \& Legal Studies, 22(3), 395-420. https://doi.org/10.1177/0964663912471552

Buisseret, P. (Ed.), (2019). Charter of core principles of the European legal profession \& Code of conduct for European lawyers Retrieved from https://www.ccbe.eu/fileadmin/speciality_distribution/public/documents/DEONTOLOGY/DEON_CoC/EN_DE ON_CoC.pdf

Chen, Y. (2014). A study on early childhood educators' aesthetic teaching beliefs and practices in Taiwan. Asia Pacific Journal of Research in Early Childhood Education, 8(3), 21-39.

European Commission. (2015). Code of Ethics of the European Union. Retrieved from https://ec.europa.eu/info/about-european-commission/service-standards-and-principles/ethics-and-good-adminis tration_en

Fredricks, J., Filsecker, M., \& Lawson, M. (Eds.), (2016). Special Issue: Student engagement and learning: theoretical and methodological advances. Learning and Instruction, 43, 1-84. https://doi.org/10.1016/j.learninstruc.2016.02.002

Jang, H., Kim, E. J., \& Reeve, J. (2016). Why students become more engaged or more disengaged during the semester: A self-determination theory dual-process model. Learning and Instruction, 43, 27-38. https://doi.org/10.1016/j.learninstruc.2016.01.002

Jones, J., Jenkin, M., \& Lord, S. (2006). Developing effective teacher performance. London, UK: Paul Chapman.

Katsavets, R. S. (2017). Professional ethics of lawyers: Manual. Kyiv, Ukraine: Alerta.

Kolstad, H. (2017). Role of art, religion, and morality in higher education. RoSE-Research on Steiner Education, $7(2), 1-17$.

Krasnolutskii, K. K. (2013). Problems of professional education development in Ukraine: modern tendencies and perspectives. Psychological and pedagogical science, 2, 24-28.

Leahy, C. M., Peterson, R. F., Wilson, I. G., Newbury, J. W., Tonkin, A. L., \& Turnbull, D. (2010). Distress levels and self-reported treatment rates for medicine, law, psychology, and mechanical engineering tertiary students: Cross-sectional study. Australian \& New Zealand Journal of Psychiatry, 44(7), 608-615. https://doi.org/10.3109/00048671003649052

Ledvinka, G. (2014). Reflection and assessment in clinical legal education: Do you see what I see? International Journal of Clinical Legal Education 9(29), 29-56. https://doi.org/10.19164/ijcle.v9i0.86

Lim, B. (2005). Aesthetic experience in a dynamic cycle: Implications for early childhood teachers and teacher educators. Journal of Early Childhood Teacher Education, 25(4), 367-373. https://doi.org/10.1080/1090102050250411

Ministry of Education and Science of Ukraine. (2018). The state of legal education in Ukraine. Analytical study based on the results of educational measurement. Kyiv, Ukraine: Mudruk S. O.

Moley, N. (2014). Confronting the challenges of ethical accountability in International Human Rights Lawyering. Stanford Journal of International Law, 50(2), 359-392.

Nilchaikovit, T. (2008). The arts of learning organization for transformative in contemplative approach 
Contemplative education: education for human development. Bangkok, Thailand: Contemplative Center Project Mahidol University.

Pechko, L. P. (2008). General and esthetical culture in education and development of a personality. Culture, experience, and imagination of a developing personality in art education, 2, 18-26.

The Lawyer Portal. (n.d.). Quiz: Would I Make a Good Lawyer? Retrieved from https://www.thelawyerportal.com/quizzes/would-i-make-a-good-lawyer-quiz/

Romanenko, Y. O., \& Chaplay, I. V. (2016). Marketing communication system within public administration mechanisms. Actual Problems of Economics, 178(4), 69-78.

Rukolianska, N. V. (2015). Professional culture and legal ethics formation of future lawyers. Pedagogy of creative personality formation in higher and general educational institutions, 41 (94), 279-286.

Semenog, O. M., \& Nasilenko, L. A. (2015). Professional communicative training of future lawyers: theory and practice. Sumy, Ukraine: The institute of adults' pedagogical education NAPS of Ukraine.

Slyvka, S. (2000). Legal deontology: problems and findings. The Ukrainian Law, 11, 118-122.

Stremmel, A. J. (2005). Turning the soul: Nurturing the inner lives of student teachers. Journal of Early Childhood Teacher Education, 25(4), 375-381. https://doi.org/10.1080/1090102050250412

Sylantiev, D., \& Inshyn, M. (2018, October 2). The higher education in the current context: problems and perspectives. The Ukrainian Voice. Retrieved from http://www.golos.com.ua/article/308165

Tszia, Ya. (2016). Professional culture as a vector of success. Innovative solutions in modern science, 8, 1-7.

Uhrmacher, P. B., Moroye, C. M., \& Conrad, B. (2016). Aesthetic, spiritual, and flow experiences: Contrasts and educational implications. Education and Culture, 32(1), 131-151. https://doi.org/10.5703/educationculture.32.1.131

Voloshyna, Ya. (2016) Peculiarities of legal counsel's professional culture. The legal journal of National Academy of the Internal Affairs, l(11), 193-204.

Waters, L., Barsky, A., Ridd, A., \& Allen, K. (2015). Contemplative education: A systematic, evidence-based review of the effect of meditation interventions in schools. Educational Psychology Review, 27(1), 103-134. https://doi.org/10.1007/s10648-014-9258-2

Yaniv, D. (2012). Dynamics of Creativity and Empathy in Role Reversal: Contributions from Neuroscience. Review of General Psychology, 16(1), 70-77. https://doi.org/10.1037/a0026580 